\title{
O RECURSO ESPECIAL ELEITORAL SOB ANÁLISE: DA TEORIA GERAL À APLICAÇÃO JURISPRUDENCIAL DE SEUS REQUISITOS DE ADMISSIBILIDADE
}

\author{
The Special Electoral Appeal under Analysis: from general theory to the \\ jurisprudential application of its admissibility requirements
}

\section{Viviane Medeiros Lima \\ (D) Volgane Oliveira Carvalho}

Resumo: Neste trabalho, traça-se um panorama da trajetória processual que leva à interposição do Recurso Especial Eleitoral (REspEl), alertando o advogado subscritor da necessidade de antever a possível apresentação do recurso perante o Tribunal e, então, preparar o processo com base em pressupostos gerais e específicos e nas hipóteses de cabimento recursais. Sob essa ótica, aborda-se os possíveis entraves à admissibilidade do Recurso Especial Eleitoral, analisada pela presidência do Tribunal Regional Eleitoral e, ainda, pelo Tribunal Superior Eleitoral, bem assim a alternativa do agravo ao TSE, em caso de REspEl não admitido. Ao final, será possível visualizar que o sucesso (provimento) do Recurso Especial Eleitoral está, via de regra, intimamente ligado à sua cuidadosa preparação, comprovando-se o cumprimento de uma das hipóteses de cabimento e de todos os pressupostos recursais, a fim de evitar, eventualmente, esbarrar-se na chamada "jurisprudência defensiva".

Palavras-chave: Recurso especial eleitoral. Juízo de admissibilidade. Jurisprudência.

\begin{abstract}
This work outlines an overview of the procedural course that leads to the filing of the Special Electoral Appeal (Recurso Especial Eleitoral - REspEl). It aims to caution the appealing attorney about the need to anticipate the possible presentation of the appeal before the Court and then prepare the case based on general and specific prerequisites and admissibility evaluation. From this perspective, the possible obstacles to the admissibility of the Recurso Especial Eleitoral are discussed, which is analyzed by the presidency of the Regional Electoral Court (Tribunal Regional Eleitoral - TRE) and also by the Superior Electoral Court (Tribunal Superior Eleitoral - TSE), as well as the alternative of the appeal (agravo) to the TSE, in the case of a rejected REspEl. The conclusion shows it is possible to understand that the success (acceptance) of the Recurso Especial Eleitoral is, as a rule, closely linked to its careful preparation and the proof of one of the situations of admissibility and all the conditions for appealing, to avoid coming up against the so-called "defensive jurisprudence" of the courts.
\end{abstract}

Keywords: Special Electoral Appeal (Recurso Especial Eleitoral). Admissibility evaluation.

Artigo recebido em 5 abr. 2021 e aprovado em 7 jul. 2021

Editor responsável: Luiz Magno Pinto Bastos Junior

DOI: https://doi.org/10.53323/resenhaeleitoral.v25i1.136 


\section{Introdução}

O processo cível-eleitoral brasileiro, com suas especificidades em relação ao processo comum, possui um sistema recursal bastante conciso e simples. Analisando-se jurisprudência do Tribunal Superior Eleitoral (TSE), o presente trabalho se propõe a estudar o Recurso Especial Eleitoral (cuja sigla constante no sistema de indexação do TSE é REspEl), que se mostra como o meio de irresignação que a parte possui para buscar o debate, em instância extraordinária, da questão de direito objeto da sua inconformidade.

A análise atenta do trâmite da espécie recursal em lume revela que, em juízo de admissibilidade, grande parte dos recursos especiais eleitorais não chega a sequer ser conhecida. Ou seja, ante a não demonstração prévia e expressa de seus pressupostos e hipóteses de cabimento, o presidente do Tribunal Regional Eleitoral, o seu relator no TSE, ou até mesmo o colegiado, negam seguimento ao recurso.

Seria tal fato, então, decorrente da inabilidade/inexperiência, na seara eleitoral, de seus subscritores ou, talvez, de excesso na aplicação das chamadas "jurisprudências defensivas"?

Destarte, o que se busca, ao final deste artigo, é demonstrar que a cuidadosa preparação do Recurso Especial Eleitoral é a via para seu provimento, evitando-se sua negativa de seguimento, de plano, em sede de juízo de admissibilidade.

Para a elaboração desta pesquisa, utilizou-se o método indutivo, baseado na exploração de dados qualitativos e quantitativos, tendo como técnica de pesquisa a análise de normas constitucionais e legais, jurisprudência e revisão bibliográfica.

\section{O recurso especial eleitoral na legislação brasileira}

O Código Eleitoral de 1965 (Lei n 4737/65) previu a possibilidade de interposição do Recurso Especial Eleitoral no seu art. 276, I, alíneas "a" e "b", quando as decisões dos tribunais regionais eleitorais contrariarem dispositivo legal ou quando houver divergência entre dois (ou mais) tribunais eleitorais, senão vejamos, verbis:

Art. 276. As decisões dos Tribunais Regionais são terminativas, salvo os casos seguintes em que cabe recurso para o Tribunal Superior: 
I - especial:

a) quando forem proferidas contra expressa disposição de lei;

b) quando ocorrer divergência na interpretação de lei entre dois ou mais tribunais eleitorais.

O Recurso Especial Eleitoral foi, também, constitucionalmente previsto no art. 121, \4º I e II, da Carta Magna de 1988. In verbis:

Art. 121.

$[\ldots]$

$\int 4^{\circ}$ Das decisões dos Tribunais Regionais Eleitorais somente caberá recurso quando:

I - forem proferidas contra disposição expressa desta Constituição ou de lei;

II - ocorrer divergência na interpretação de lei entre dois ou mais tribunais eleitorais.

Note-se que, comparando-se as duas previsões, o Código Eleitoral (cronologicamente mais antigo) não menciona a hipótese da decisão judicial que contrarie a constituição como passível de ser impugnada via REspEl, ao passo em que tal possibilidade veio expressa na própria Constituição Federal de 1988 que, dessa forma, recepcionou o Código Eleitoral por, com ela, demonstrar compatibilidade.

Assim, diferentemente do Recurso Especial comum, que direciona a demanda recursal ao Superior Tribunal de Justiça (STJ), e cujo objeto é acórdão de Tribunal de Justiça Estadual ou de Tribunal Regional Federal que contrarie tratado ou lei federal, julgue válido ato de governo local face lei federal ou atribua à lei federal interpretação diversa da interpretação realizada por outro tribunal (art. 105, III, da CF/88), o Recurso Especial Eleitoral possui, nesse aspecto, amplo efeito devolutivo, por submeter ao TSE, também, matéria de índole constitucional.

Os supracitados dispositivos constitucional e legal (código eleitoral) que delimitam as hipóteses de cabimento do Recurso Especial Eleitoral são, também, complementados por dispositivos do Código de Processo Civil (supletiva e subsidiariamente) ${ }^{1}$ e pelas súmulas do TSE, os quais também são delineados ao longo desta obra, juntamente com o entendimento jurisprudencial do TSE acerca dos tópicos abordados.

${ }^{1}$ Art. 2o, parágrafo único, da Res. TSE no 23.478/2016.

Resenha Eleitoral, Florianópolis, v. 25, n. 1, p. 139-164, jan./jun.2021 
Segundo José Jairo Gomes (2020) são considerados pressupostos específicos do Recurso Especial Eleitoral: 1) decisão de tribunal regional eleitoral e; 2) o prequestionamento da questão jurídica.

As hipóteses de cabimento são, de forma ampla, aquelas expostas na Constituição Federal, em seu art. 121, \ 4º alíneas I e II, ou seja, a demonstração de contrariedade à disposição expressa da CF/88 ou de lei federal, ou, ainda, a demonstração de divergência entre dois ou mais tribunais eleitorais na interpretação de lei.

A análise do REspEl em juízo de admissibilidade sustenta-se, portanto, na demonstração, pelo recorrente, de todos os pressupostos gerais (comuns aos recursos) e específicos, bem como de uma das hipóteses de cabimento, conforme se esmiuçará nos tópicos posteriores.

\section{Características gerais do recurso especial eleitoral}

Dotado de natureza de recurso em sede extraordinária, o Recurso Especial Eleitoral é interposto ainda perante o Presidente do Tribunal Regional Eleitoral prolator da decisão colegiada que se pretende contestar.

Assim, ao ser submetido à análise própria, já deve possuir contornos fáticos (quaestio facti) expressamente reconhecidos e delineados na instância ordinária, não sendo possível levar esse debate para a sede extraordinária, o que é característica comum em recursos dessa espécie.

Preciso é o entendimento de José Jairo Gomes (2020, p.165) acerca do tema:

Tais recursos [os de natureza excepcional] possuem regime próprio e função constitucional específica, não sendo vocacionados para a discussão da existência ou inexistência de fato ou do modo como ele ocorreu (quaestio facti). Assim a narrativa fática deve necessariamente encontra-se resolvida nas instâncias ordinárias por ocasião da interposição. (...) Ou seja, nos recursos excepcionais, discute-se apenas os fatos da causa tal qual estabelecidos pelo tribunal recorrido.

Quanto a seus efeitos, importa mencionar que o REspEl não é dotado de efeito suspensivo da eficácia do acórdão recorrido, dependendo a parte recorrente, para tanto, de requerimento específico ao presidente do Tribunal Regional recorrido (entre a interposição do recurso e a publicação 
da decisão de admissibilidade) ou ao TSE (após a publicação da decisão de admissibilidade) $)^{2}$.

Quanto ao trâmite do Recurso Especial Eleitoral, registre-se que sua interposição se dá perante o Tribunal Regional Eleitoral recorrido (em regra, direcionado a seu presidente), devendo ser submetido ao crivo de admissibilidade, tanto no tribunal regional de origem, quanto no TSE (relator/colegiado).

O juízo de admissibilidade a que deve ser submetido o REspEl será melhor explanado ainda nesta obra.

\subsection{Esboço comparativo entre o recurso especial eleitoral e o recurso ordinário eleitoral}

Importante estabelecer nitidamente os elementos que distanciam e individualizam o Recurso Especial Eleitoral (REspEl) do Recurso Ordinário (RO). Ambos são direcionados ao TSE, com prazo de interposição idêntico perante o TRE, porém com previsões de cabimento e natureza diversos.

Conquanto o REspEl tenha previsão nos incisos I e II do art. 121, \ 4, da CF/88 (e art. 276, I, “a” e "b”, do CE), e seja recurso de natureza

\footnotetext{
${ }^{2}$ CPC. Art. 995. Os recursos não impedem a eficácia da decisão, salvo disposição legal ou decisão judicial em sentido diverso.

Parágrafo único. A eficácia da decisão recorrida poderá ser suspensa por decisão do relator, se da imediata produção de seus efeitos houver risco de dano grave, de difícil ou impossível reparação, e ficar demonstrada a probabilidade de provimento do recurso.

(...)

Art. 1029.

$[\ldots]$

$\int 5^{\circ} \mathrm{O}$ pedido de concessão de efeito suspensivo a recurso extraordinário ou a recurso especial poderá ser formulado por requerimento dirigido:

I - ao tribunal superior respectivo, no período compreendido entre a interposição do recurso e sua distribuição, ficando o relator designado para seu exame prevento para julgá-lo; I - ao tribunal superior respectivo, no período compreendido entre a publicação da decisão de admissão do recurso e sua distribuição, ficando o relator designado para seu exame prevento para julgá-lo;

II - ao relator, se já distribuído o recurso;

III - ao presidente ou vice-presidente do tribunal local, no caso de o recurso ter sido sobrestado, nos termos do art. 1.037.
} 
extraordinária, o RO tem suas hipóteses de cabimento dos incisos III, IV e $\mathrm{V}^{4}$, da citada norma constitucional (e art. 276, II, “a” e "b", do CE), e sua natureza é de (como o próprio nome antecipa) recurso ordinário, como também o são a apelação e o recurso eleitoral inominado. Portanto, a matéria fática e jurídica a ser devolvida (efeito devolutivo) para análise do TSE no RO é bem mais ampla que no REspEl e sua fundamentação é livre.

Ademais, diferentemente do que ocorre com o REspEl, com base

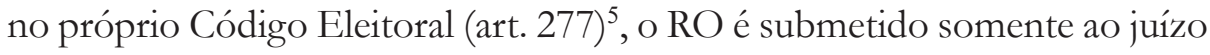
de admissibilidade no TSE, cabendo ao TRE, prolator do acórdão recorrido, providenciar a intimação para contrarrazões e a remessa ao tribunal superior.

Quanto à possibilidade de aplicação do princípio da fungibilidade recursal, ou seja, receber-se o REspEl interposto em lugar do RO (ou vice-versa), frise-se que a jurisprudência do TSE, que permitia a aplicação da fungibilidade em casos de presença dos requisitos de admissibilidade do recurso efetivamente cabível $^{6}$, foi recentemente alterada (por maioria),

\footnotetext{
${ }^{3}$ Aqui abro um parêntese para observar que a Súmula TSE no 36, mesmo sendo derivada de uma revisão de súmulas pelo TSE - finalizada no início de 2017, limitou a previsão de interposição do recurso ordinário aos incisos III e IV, do art. 121, \4º da CF/88, o que não exclui a previsão contida no inciso $\mathrm{V}$ da referida norma constitucional, que permanece hígida.
}

${ }^{4} \mathrm{CF} / 88$. Art. 121. [...] $\int 4^{\circ}-$ Das decisões dos Tribunais Regionais Eleitorais somente caberá recurso quando: $[\ldots]$

III - versarem sobre inelegibilidade ou expedição de diplomas nas eleições federais ou estaduais;

IV - anularem diplomas ou decretarem a perda de mandatos eletivos federais ou estaduais;

V - denegarem habeas corpus, mandado de segurança, habeas data ou mandado de injunção.

${ }^{5}$ Art. 277. Interposto recurso ordinário contra decisão do Tribunal Regional, o presidente poderá, na própria petição, mandar abrir vista ao recorrido para que, no mesmo prazo, ofereça as suas razões.

Parágrafo único. Juntadas as razões do recorrido, serão os autos remetidos ao Tribunal Superior.

6 “[...] 3. Em análise do apelo especial, nada obstante não seja o recurso adequado à hipótese, uma vez não observado o previsto nos arts. 121, \ 4․ III, da Constituição Federal e 276, II, a, do Código Eleitoral, verifica-se que, em vista do preenchimento dos requisitos de admissibilidade do recurso cabível e do princípio da fungibilidade recursal, deve ser recebido como ordinário. Precedentes". (TSE, RO - Embargos de Declaração em Recurso Ordinário no 060162806 - CAMPO GRANDE - MS. Acórdão de 05/03/2020. Relator(a) Min. Tarcisio Vieira De Carvalho Neto. Publicação: DJE - Diário da justiça eletrônica, Tomo 71, Data 14/04/2020, Página 75-86). 
firmando-se o entendimento pela impossibilidade de recebimento de um recurso pelo outro, considerando a situação um erro grosseiro.

Nesse sentido:

[...] 6. O princípio da fungibilidade recursal, previsto no art. 810, do Código de Processo Civil de 1939, não foi repetido nos diplomas processuais civis de 1973 e 2015. Contudo, continua a ser aplicado pelas Cortes Nacionais, desde que observada a existência de dúvida objetiva e a inocorrência de erro grosseiro. 7. O sistema normativo específico que disciplina e distingue as hipóteses de recurso especial eleitoral e de recurso ordinário, na Justiça Eleitoral, extraído da leitura conjunta do art. 121, $\int 4^{\circ}$, incisos I a V, da Constituição Federal, do art. 276, incisos I e II, do Código Eleitoral e da Súmula 36 do TSE, impõe o degredo da dúvida objetiva para as hipóteses nele contidas e obsta a utilização do princípio da fungibilidade recursal. 8 . A inobservância do mencionado sistema normativo específico que disciplina o acesso, pela via recursal, ao Tribunal Superior Eleitoral descortina inescusável erro grosseiro que também obsta a aplicação do princípio da fungibilidade recursal. 9. É inadmissível a interposição de recurso especial eleitoral contra decisão que produz os efeitos previstos no art. 121, \ $4^{\circ}$, inciso IV, da Constituição Federal.

(TSE, RO - Agravo Regimental em Recurso Ordinário nº 060008680 - FLORIANÓPOLIS - SC. Acórdão de 01/09/2020. Relator(a) Min. Tarcisio Vieira De Carvalho Neto. Relator(a) designado(a) Min. EDSON FACHIN. Publicação: DJE - Diário da justiça eletrônica, Tomo 211, Data 20/10/2020, Página 0).

[...] 3. É inadmissível a interposição de recurso especial eleitoral contra decisão que produz os efeitos previstos no art. 121, $\int 4^{\circ}$, IV, da Constituição Federal, uma vez que, no caso, o cabível é o recurso ordinário. [...] 6. Nesse diapasão, tendo em consideração a inexistência de dúvida sobre o cabimento do recurso ordinário eleitoral na quadra das hipóteses de perda de mandato, segue-se como consectário que, nessas situações, não se afigura viável a aplicação do princípio da fungibilidade recursal diante da interposição do recurso especial eleitoral, de maneira a admitir como ordinário o recurso especial indevidamente protocolado. $\mathrm{O}$ erro da parte, em tal caso, afigura-se grosseiro. Doutrina.

(TSE, AI - Agravo Regimental em Agravo de Instrumento $\mathrm{n}^{\mathrm{Q}}$ 060009463 - BELO HORIZONTE - MG. Acórdão de 29/10/2020. Relator(a) Min. Edson Fachin. Publicação: DJE - Diário da justiça eletrônico, Tomo 227, Data 09/11/2020). 


\section{Juízo de admissibilidade}

O procedimento descrito no art. 278 do Código Eleitoral se refere à análise de admissibilidade do Recurso Especial Eleitoral pelo presidente do TRE, conferindo prazo (impróprio) ao tribunal para juntada, conclusão, decisão e intimação para contrarrazões. Confira-se:

Art. 278. Interposto recurso especial contra decisão do Tribunal Regional, a petição será juntada nas 48 (quarenta e oito) horas seguintes e os autos conclusos ao presidente dentro de 24 (vinte e quatro) horas.

$\int 1^{\circ} \mathrm{O}$ presidente, dentro em 48 (quarenta e oito) horas do recebimento dos autos conclusos, proferirá despacho fundamentado, admitindo ou não o recurso.

$\S 2$ Admitido o recurso, será aberta vista dos autos ao recorrido para que, no mesmo prazo, apresente as suas razões.

$\int 3^{\circ} \mathrm{Em}$ seguida serão os autos conclusos ao presidente, que mandará remetê-los ao Tribunal Superior.

Conforme referido anteriormente, o momento da análise da admissibilidade representa um significativo gargalo para o seguimento do recurso em pauta, situação que é bastante representativa na obtenção das conclusões desta pesquisa.

Chamam a atenção os dados quantitativos obtidos no Sistema de Processo Judicial Eletrônico (PJe), em relação aos processos que tramitaram nos anos de 2019 e 2020 no Tribunal Regional Eleitoral do Maranhão (TRE-MA), os quais confirmam, matematicamente, o que a experiência prática já anunciava: o alto índice de negativa de seguimento dos recursos especiais eleitorais interpostos, em juízo de admissibilidade realizado no TRE-MA. Confira-se:

Tabela 1 - Distribuição de decisões proferidas pela Presidência do TRE-MA, em sede de juízo de admissibilidade do Recurso Especial Eleitoral, nos anos de 2019 e 2020

\begin{tabular}{|l|c|}
\hline Recursos especiais eleitorais admitidos & $82(47,13 \%)$ \\
\hline Recursos especiais eleitorais não admitidos & $92(52,87 \%)$ \\
\hline Total de REspEl analisados & 174 \\
\hline
\end{tabular}

Fonte: Sistema de Processo Judicial Eletrônico (PJe $-2^{\circ}$ grau) / TRE-MA

Com base nos dados levantados, é imperioso reconhecer a necessidade de que as partes repensem a importância e o valor dos recursos. A 
consciência dos atores processuais é uma necessidade atual, mormente quando se verifica a entronização do princípio da boa-fé processual no Código Fux.

O filtro judicial, ultimado através do juízo de admissibilidade, não deveria atingir um percentual tão impactante de Recursos Especiais Eleitorais, pois este é um indicativo severo da desnecessidade, ao menos em tese, de que a decisão mereça ser contestada, evitando-se assim o exercício abusivo do direito de recorrer.

Nesse ponto, registro trecho da opinião do advogado Diógenes de Brito Tavares que, em artigo intitulado "É preciso defender-se da jurisprudência defensiva"7, reflete sobre a origem e o objetivo da chamada "jurisprudência defensiva" dos tribunais frente ao exercício do direito de recorrer do jurisdicionado. In verbis:

(...) o termo "defensiva" exclui qualquer polissemia. O predicado está claramente a indicar que se trata de uma jurisprudência que repele um ataque. Mas é de se indagar: de quem se defende a jurisprudência defensiva? O agressor, aqui, não é outro senão o abuso. Mais propriamente, o abuso no exercício do direito de recorrer.

Registre-se, por importante, que o que se vê na Tabela 1 é certamente reprisado, talvez até em patamares mais significativos, em outros Tribunais Regionais Eleitorais no País. Segundo Gomes (2020, p. 207), "na prática, é muito frequente a não admissão de recurso especial eleitoral”. Assim, é fundamental ao operador do Direito Eleitoral ter visão ampla do trâmite processual que pode levar à interposição do REspEl, evitando sucumbir logo na fase da admissibilidade.

Em regra ${ }^{8}$, o juízo de admissibilidade do REspEl é realizado em dois momentos independentes: primeiro, pela presidência ${ }^{9}$ do tribunal regional recorrido, e depois - sendo admitido diretamente ou após provimento do Agravo -, já no TSE, são novamente analisados os requisitos legais para admissão (pressupostos e hipóteses de cabimento).

\footnotetext{
${ }^{7}$ https://www.conjur.com.br/2020-set-04/diogenes-tavares-defender-jurisprudencia-defensiva.

${ }^{8}$ A LC nº 64/1990, art. 12, parágrafo único prevê inexistência do juízo de admissibilidade nos recursos em processos de registro de candidaturas.

${ }^{9}$ Considerando-se a experiência prática no TRE-MA, excepcionalmente, o juízo de admissibilidade será realizado por decisão do Vice-Presidente do Tribunal, nos casos pontuais em que o acórdão recorrido tiver sido relatado pelo Presidente (que, regimentalmente, possui direito a voto).
} 
Ademais, há independência entre as análises realizadas pelos dois tribunais/graus de jurisdição. Não há, portanto, usurpação ou invasão de competência do $\operatorname{TSE}^{10}$ quando a análise das hipóteses de cabimento pelo TRE adentra no próprio mérito do recurso ${ }^{11}$, o que é extremamente comum na prática.

Observa-se que a análise deve ocorrer nas duas cortes, pois, conquanto possa parecer que o crivo de admissibilidade realizado pelo Tribunal Superior seja o mais importante e supra eventual omissão do Tribunal a quo, o entendimento do TSE (baseado em jurisprudência do Superior Tribunal de Justiça ${ }^{12}$ é no sentido de ser imprescindível, apesar de não vinculativo, o juízo de admissibilidade do Tribunal recorrido.

Cite-se, como exemplo, trecho da decisão monocrática na qual o relator no TSE suspendeu o julgamento de um dos REspEl interpostos naquele processo e determinou o retorno dos autos ao TRE-MA, para que fosse proferida a decisão em relação ao outro Recurso Especial (que, por lapso, havia sido omitida).

Sabe-se que o recurso especial eleitoral submete-se ao duplo juízo de admissibilidade, sendo o primeiro realizado perante o Tribunal Regional Eleitoral de origem e o segundo nesta Corte Superior.

A jurisprudência do Tribunal Superior Eleitoral é firme no sentido de que o juízo de admissibilidade feito na instância de origem não vincula a análise deste Tribunal (AgR-AI n 841/GO, Rel. Min. Luís

10 “[... 2. O Tribunal Regional pode, por ocasião da análise da admissibilidade do recurso especial, adentrar no mérito recursal sem que isso implique usurpação de competência. Isso porque este Tribunal não está vinculado ao juízo de admissibilidade realizado na instância de origem". (TSE, AI - Agravo Regimental em Agravo de Instrumento n⿳o 32152 - IGARAPÉ DO MEIO - MA. Acórdão de 26/09/2019. Relator(a) Min. Luís Roberto Barroso. Publicação: DJE - Diário da justiça eletrônica, Tomo 216, Data 08/11/2019, Página 99/100).

${ }^{11}$ Esse entendimento é tão pacificado, tanto no TSE quanto na doutrina, que seria de bom alvitre que, na prática, o argumento da invasão de competência não fosse aduzido, seja nas contrarrazões ao REspEl, seja no Agravo ao TSE, sob pena de se fortalecer, indiretamente, eventual contra argumento relacionado ao abuso do direito de recurso.

12 “[...] 2. O recurso especial se submete a duplo juízo de admissibilidade, sendo certo que o juízo primevo, realizado no Tribunal a quo, apesar de provisório (por que não vincula o STJ), é obrigatório. 3. Deixando o Tribunal estadual de realizar o imprescindível juízo de admissibilidade, deve ser determinado o retorno dos autos à origem para o regular processamento do recurso. 4. Agravo interno desprovido." (STJ. AgInt-AREsp n 1336384/SP, Rel. Min. Gurgel de Faria, Primeira Turma, DJe de 20.5.2019). 
Roberto Barroso, DJe de 25.02.2019). Contudo, registra-se que a inexistência de vinculação entre o juízo definitivo e o juízo primevo não dispensa a realização deste. [omissis]

Considerando que, no caso, o Presidente do TRE/MA deixou de realizar o juízo de admissibilidade do recurso interposto por [omissis], é indispensável o retorno dos autos à origem para o regular processamento do apelo.

Ante o exposto, determino o retorno dos autos ao TRE/MA para que exerça o juízo de admissibilidade do recurso especial manejado por [omissis].

(TSE, AI em REspEl no 213-65.2016.610.0096 / Zé Doca-MA. Rel. Min. EDSON FACHIN. Decisão monocrática de 26/08/2019. Publicada DJE - Diário de justiça eletrônico - 30/08/2019 - Página 26-28).

Por fim, mas não menos importante, frise-se que a decisão da presidência do TRE, seja de admissão ou inadmissão do Recurso Especial Eleitoral, sempre é proferida antes da manifestação da parte ex adversa. O art. 278, \ 2을 do Código Eleitoral, menciona o trâmite de intimação para contrarrazões em caso de admissão do recurso.

Caso o TRE negue seguimento ao Recurso Especial, há a possibilidade de lançar-se mão do Agravo para o TSE, o qual será, ainda na instância ordinária, objeto de intimação para juntada de contrarrazões pelo Agravado e, no mesmo prazo, contrarrazões ao Recurso Especial Eleitoral. Ambos os recursos, com suas respectivas contraminutas, serão submetidos ao TSE. Assim dispõe expressamente a Súmula TSE no 71: "na hipótese de negativa de seguimento ao recurso especial e da consequente interposição de agravo, a parte deverá apresentar contrarrazões tanto ao agravo quanto ao recurso especial, dentro do mesmo tríduo legal".

\subsection{Pressupostos}

\subsubsection{Pressupostos gerais}

A legitimidade e o interesse recursal, bem assim a tempestividade do apelo, podem ser considerados pressupostos gerais do Recurso Especial Eleitoral e devem ser avaliados no juízo de admissibilidade. Ausente qualquer deles, deve ser negado seguimento ao recurso.

O prazo para interposição do Recurso Especial Eleitoral é de 3 (três) dias, à exceção daquele que for lançado em processo que envolva 
"direito de resposta", cujo prazo é de 24 (vinte e quatro) horas, vez que sua própria natureza demanda extrema celeridade no período eleitoral.

\subsubsection{Pressupostos específicos}

\subsubsection{Decisão judicial de TRE}

As previsões normativas (legal e constitucional) para a interposição do Recurso Especial Eleitoral mencionam que a "decisão de tribunal regional eleitoral” é o objeto do recurso. Assim, será contra uma decisão do TRE que o REspEl se voltará. Porém, não há menção expressa ao conteúdo ou à natureza dessa decisão.

De fato, a decisão colegiada, nomeada de "acórdão", é aquela mencionada na CF/88 e no Código Eleitoral como "decisão do Tribunal Regional Eleitoral", uma vez que da decisão monocrática de relator no TRE, ainda cabe o Agravo Interno para o pleno.

Ademais, segundo José Jairo Gomes (2020, p. 167), "só são impugnáveis por recurso especial decisões proferidas no âmbito do exercício das funções jurisdicionais do tribunal regional, bem como as decisões de natureza administrativo-eleitoral se houver expressa previsão normativa”, excluindo-se, portanto, as decisões de caráter estritamente administrativo, bem assim as deliberações derivadas das funções consultiva (CE, art. 30, VIII) e normativa do TSE.

Para melhor delinear o entendimento do Egrégio TSE, cito decisão monocrática na qual o Relator, Min. Luiz Fux, julgando caso concreto que envolvia a negativa de registro de diretório regional de um partido, assim doutrinou:

Como se sabe, essa Justiça Especializada desempenha funções de natureza híbrida, tanto administrativa quanto jurisdicional, cujos regramentos se especificam de acordo com o tipo de processo a que subjazem.

A função jurisdicional da Justiça Eleitoral se volta para a solução dos conflitos intersubjetivos de viés eleitoral que reclamam solução imparcial do Estado-juiz, tais como propaganda eleitoral irregular, captação ilícita de sufrágio, conduta vedada, abuso do poder político e outros. Atuando administrativamente, esta Justiça é responsável pelos atos relativos ao preparo e à organização de todo o processo eleitoral, tais quais inscrição de eleitores, transferência de domicílio eleitoral, organização dos locais de votação, registro de partidos 
políticos, entre outros. Precisamente por se tratar de processo de cunho administrativo, não se afigura cabível a interposição de recurso especial eleitoral em face de decisão de Tribunal Regional Eleitoral relativa ao indeferimento do pedido de registro de órgão partidário regional por ausência de comprovação de apoiamento dos eleitores, visto que esse instrumento impugnatório possui viés nitidamente jurisdicional. O contrário implicaria indevida "mesclagem a contrariar a organicidade e dinâmica do Direito" (AgR-AI no 11576/MG, Rel. Min. Marco Aurélio, DJe de 23/9/2013).

(TSE, Proc. no 294-13.2015.604.0000 / Manaus-AM. Re. Min. LUIZ FUX. Decisão de 05/02/2018. Publicação DJe - 22/02/2018 - Página 77-78).

Por fim, registre-se que a Súmula TSE n⿳o 31 impede o conhecimento de Recurso Especial Eleitoral tirado contra acórdão que decide sobre pedido de medida liminar. A justificativa para a exclusão da decisão colegiada que enfrente pedido liminar, seria a de que, por sua natureza interlocutória, não há teor de definitividade nesse acórdão, podendo a medida liminar ser revista e alterada em outra fase processual.

Recorde-se que, para a admissão do Recurso Especial Eleitoral, não pode haver pendência recursal acerca da questão de direito controversa, tema abordado pela Súmula TSE n 25, ao expressar que "é indispensável o esgotamento das instâncias ordinárias para a interposição de recurso especial eleitoral".

\subsubsection{Prequestionamento da matéria jurídica}

Conforme já aduzido neste trabalho, pela própria característica de recurso extraordinário, a matéria objeto da irresignação contida no REspEl deve ser somente a questão de direito (quaestio iuris), o que não quer dizer que os fatos sejam excluídos da análise, mas sim que, em relação aos contornos fáticos, o que ficou estabelecido na instância ordinária não pode ser reanalisado visando a alterá-lo. Assim, não se pode questionar na instância superior como se estabeleceram os fatos na instância ordinária, sua existência ou inexistência.

Em sede de Recurso Especial Eleitoral, os fatos, tal como postos na instância ordinária, são analisados como fatos da causa e integram a análise da questão jurídica objeto do recurso. Dito isto, o TSE, por meio da 
Súmula no $24^{13}$, veta a admissão do REspEl no qual se busque a alteração do acórdão regional, partindo pura e simplesmente da rediscussão dos fatos e provas, o que é, muito frequentemente, o motivo principal da inadmissibilidade dos recursos especiais no TSE.

O que pode ocorrer, na verdade, é o chamado reenquadramento jurídico dos fatos, quando o TSE entende equivocado o tratamento da quaestio iuris debatida, em face das premissas (fatos e provas) estabelecidas no acórdão recorrido. Confira-se alguns exemplos na jurisprudência do TSE:

[...] 8. A hipótese não demanda reexame probatório, providência vedada em sede extraordinária pela Súmula 24/TSE, mas apenas o reenquadramento jurídico dos fatos incontroversos contidos no aresto a quo.

(TSE, REspEl - Agravo Regimental no Recurso Especial Eleitoral no 060011382 - Santa Cruz Cabralia - BA. Acórdão de 18/12/2020. Relator(a) Min. LUIS FELIPE SALOMÃO. Publicação: PSESS Publicado em Sessão, Data 18/12/2020).

[...] 3. O reenquadramento jurídico dos fatos, quando cabível, é restrito às premissas assentadas pela instância regional e não se confunde com o reexame e a revaloração do caderno probatório.

(TSE, AI - Agravo Regimental em Agravo de Instrumento no 36612 - Bela Cruz - CE. Acórdão de 24/09/2020. Relator(a) Min. EDSON FACHIN. Publicação: DJE - Diário da justiça eletrônica, Tomo 199, Data 05/10/2020).

[...] 2. O reenquadramento jurídico dos fatos, que não se confunde com o reexame do arcabouço fático-probatório, é possível na estreita via do recurso especial eleitoral, por se tratar de quaestio iuris. Precedente.

(TSE, REspEl - Agravo Regimental em Recurso Especial Eleitoral $\mathrm{n}^{\circ}$ 060088554 - São Sebastião do Passe - BA. Acórdão de 18/08/2020. Relator(a) Min. TARCISIO VIEIRA DE CARVALHO NETO. Publicação: DJE - Diário da justiça eletrônica, Tomo 176, Data 02/09/2020, Página 0).

Assim, tanto os fatos quanto a questão jurídica suscitada no Recurso Especial devem ser efetivamente debatidos pela instância regional para serem analisados pelo TSE.

${ }^{13}$ Súmula TSE no 24: "Não cabe recurso especial eleitoral para simples reexame do conjunto fático-probatório". 
A experiência prática demonstra que a menção e descrição, no acórdão regional, das provas apresentadas na fase instrutória, bem como o delineamento dos fatos, contribuem para o provimento do recurso no TSE, com a conclusão de reenquadramento jurídico dos fatos.

Deveras, a parte que se sentiu prejudicada com o resultado declarado no acórdão regional, deve assegurar-se de que, para interpor Recurso Especial, não basta, por exemplo, que a transcrição dos depoimentos testemunhais que sejam, em tese, favoráveis ao seu entendimento esteja expressa nas razões de seu recurso ao TSE, mas sim, que conste expressamente no acórdão recorrido, entendendo-se como tal, por força do art. 941, \ 3², do $\mathrm{CPC}^{14}$, também o voto vencido declarado, que integra o acórdão.

Nesse caso, o prequestionamento da matéria jurídica, considerado como a apreciação da tese de direito pela decisão recorrida, deve ser diligentemente buscado pela parte interessada, ainda na instância ordinária, via Embargos de Declaração (art. 275 do Código Eleitoral e art. 1022 e seguintes do CPC).

Frise-se que, ao lançar mão dos embargos declaratórios (arguindo obscuridade, contradição, omissão ou erro material), não deve haver inovação, ou seja, a matéria fática e jurídica que se pretende prequestionar não pode estar surgindo pela primeira vez nos autos, o que ressalta ainda mais a necessidade de plena diligência do advogado eleitoralista no trâmite processual e no preparo de uma possível interposição de REspEl.

Se forem úteis para reforçar o argumento recursal, é possível (e até aconselhável), portanto, interpor os embargos aclaratórios para requerer a transcrição, no acórdão, de depoimentos testemunhais colhidos na fase instrutória, bem como para ter a juntada das notas taquigráficas de voto vencido declarado, caso não tenha sido juntado por escrito ${ }^{15}$.

Dessa forma, é imprescindível, neste tópico, citar a Súmula TSE no 72 , que reza que "é inadmissível o recurso especial eleitoral quando a

\footnotetext{
${ }^{14}$ Art. 941, \3, do CPC: “O voto vencido será necessariamente considerado parte integrante do acórdão para todos os fins legais, inclusive o de prequestionamento".

${ }^{15}$ Em regra, a Secretaria Judiciária do Tribunal faz constar no resultado do julgamento publicado quais membros da Corte acompanharam o relator e quais foram vencidos. A não declaração do voto vencido é passível de nulidade do acórdão (exceto quando o juiz já tiver seu biênio de atuação encerrado - RESPE nº 62624, Relator(a) Min. Sergio Silveira Banhos, Publicação: DJE 27/08/2020), mas não do julgamento em si (STJ, REsp 1.729.143, rel. Min. Nancy Andrighi, Terceira Turma, DJE de 15.2.2019).
} 
questão suscitada não foi debatida na decisão recorrida e não foi objeto de embargos de declaração”. Confira-se algumas aplicações práticas no TSE:

[...] 6. A alegação de enquadramento da conduta do recorrido na hipótese do item 1 da alínea e do inciso I do art. 1ำ da LC 64/90, pela suposta prática de crime contra a administração pública, não foi examinada pelo TRE, carecendo do necessário prequestionamento. Óbice da Súmula 72 TSE.

(TSE, REspEl - Recurso Especial Eleitoral no 060020923 - Crisópolis- BA. Acórdão de 18/12/2020. Relator(a) Min. SERGO SILVEIRA BANHOS. Publicação: PSESS - Publicado em Sessão, Data 18/12/2020).

[...] 3. Quanto à tese de necessidade de conversão do feito em diligência, esclareceu-se que a medida não fora pleiteada na instância de origem, resultando precluso o tema, de modo a atrair a Súmula 72/ TSE por falta de prequestionamento, requisito exigível ainda que as alegações aduzidas se refiram a matéria de ordem pública.

(TSE, REspEl - Embargos de Declaração no Agravo Regimental no Recurso Especial Eleitoral nº 060513140 - Rio de Janeiro - RJ. Acórdão de 03/12/2020. Relator(a) Min. LUIS FELIPE SALOMÃO. Publicação: DJE - Diário da justiça eletrônica, Tomo 264, Data 18/12/2020, Página 0).

Ressalte-se que, nessa temática, com vistas à interposição do Recurso Especial Eleitoral, os Embargos de Declaração são a derradeira estratégia de preparação do processo que dispõe a parte recorrente na instância ordinária, objetivando o debate de normas constitucionais, legais e jurisprudenciais sobre os fatos narrados e os argumentos de defesa desenvolvidos.

Este recurso integrativo tem relevante importância para eventual interposição de Recurso Especial Eleitoral, caso a matéria de direito trazida expressamente como argumento nos autos - desde o recurso eleitoral inominado ou suas contrarrazões -, não tenha sido debatida e decidida pelo acórdão regional (mesmo que a decisão the tenha sido desfavorável).

Acerca dos declaratórios interpostos previamente ao REspEl, caberia um estudo mais aprofundado, digno até de um artigo científico próprio, acerca das características e dos objetivos específicos destes embargos, principalmente em relação ao prequestionamento implícito das matérias jurídicas e ao pedido de efeito modificativo do acórdão. 


\subsection{Hipóteses de cabimento}

Para a interposição e a análise positiva do Recurso Especial Eleitoral, em juízo de admissibilidade, necessário que ao menos umas das suas hipóteses de cabimento seja argumentada pelo recorrente.

As hipóteses de cabimento estão consignadas, como anteriormen-

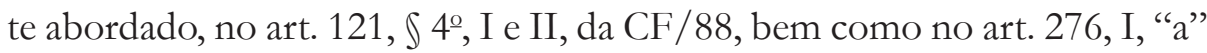
e "b", do Código Eleitoral e serão tratadas individualmente a seguir.

\subsubsection{Contrariedade a disposição expressa na Constituição Federal}

Por previsão constitucional, a parte irresignada com o que decidido no acórdão regional pode se utilizar de Recurso Especial Eleitoral alegando ofensa a específica norma da Carta Magna. Assim reza o normativo: "Art. 121. [...] \ 4º Das decisões dos Tribunais Regionais Eleitorais somente caberá recurso quando: I - forem proferidas contra disposição expressa desta Constituição ou de lei [...]".

Conforme mencionado neste artigo, o Recurso Especial Eleitoral difere do Recurso Especial comum, previsto no art. 105, III, da CF/88, por poder submeter ao TSE, antes mesmo que ao próprio Supremo Tribunal Federal (STF), matéria de índole constitucional que já tenha sido debatida e decidida no acórdão recorrido, possuindo, portanto, amplo efeito devolutivo em relação ao Recurso Especial direcionado ao Superior Tribunal de Justiça.

Assim, na seara eleitoral, não é necessária a interposição de dois recursos excepcionais em separado (especial e extraordinário), caso coexistam os fundamentos de contrariedade à norma constitucional e à lei. Basta que a questão constitucional tenha sido prequestionada no acórdão regional recorrido para ser objeto de Recurso Especial Eleitoral. Ademais, em sendo desprovido o REspEl, aí sim, em face do acórdão do TSE, é cabível a interposição de recurso extraordinário perante o STF, com a devida comprovação da repercussão geral.

Importante aqui ressaltar que a contrariedade do acórdão regional deve se referir a dispositivo constitucional expresso, ou seja, a descrição desta hipótese de cabimento, nas razões do recurso, deve direcionar claramente qual dispositivo constitucional a decisão recorrida contrariou. 
Não cabe, portanto, ofensa indireta, implícita ou reflexa à $\mathrm{CF} / 88$ para justificar a interposição de Recurso Especial Eleitoral com fulcro na hipótese do art. $121, \$ 4^{\circ}$, I, da CF/88. Nesse sentido, confiram-se entendimentos do STF:

[...] 2. A violação reflexa e oblíqua da Constituição Federal decorrente da necessidade de análise de malferimento de dispositivo infraconstitucional torna inadmissível o recurso extraordinário. Precedente: ARE 667.918-AgR, Primeira Turma, DJe de 28.3.2012. 3. Os princípios da legalidade, do devido processo legal, da ampla defesa e do contraditório, da motivação das decisões judiciais, bem como os limites da coisa julgada, quando a verificação de sua ofensa dependa do reexame prévio de normas infraconstitucionais, revelam ofensa indireta ou reflexa à Constituição Federal, o que, por si só, não desafia a abertura da instância extraordinária.

(STF, ARE 673734 ED / MS. EMB.DECL. NO RECURSO EXTRAORDINÁRIO COM AGRAVO. Relator(a): Min. LUIZ FUX. Julgamento: 22/05/2012. Publicação: 18/06/2012. Órgão julgador: Primeira Turma. Publicação DJe-118 DIVULG 15-06-2012 PUBLIC 18-06-2012).

\subsubsection{Contrariedade a disposição expressa na legislação federal}

A segunda hipótese de cabimento para a interposição do Recurso Especial Eleitoral leva em consideração o fundamento de contrariedade do acórdão regional a dispositivo expresso de lei.

Tal hipótese está prevista no mesmo dispositivo constitucional já transcrito alhures (art. 121, \4을 inciso I), bem como no art. 276, I, “a”, do Código Eleitoral. Confira-se:

Art. 276. As decisões dos Tribunais Regionais são terminativas, salvo os casos seguintes em que cabe recurso para o Tribunal Superior: I - especial:

a) quando forem proferidas contra expressa disposição de lei; [...]

Da mesma forma, e até por constar, como dito, no mesmo dispositivo constitucional, o argumento recursal de contrariedade do acórdão regional deve se referir a dispositivo legal expresso. 
Por "lei", entenda-se, in casu, a lei federal de cunho eminentemente eleitoral, incluindo-se as resoluções do Tribunal Superior Eleitoral (e não de TRE, frise-se), que são expedidas no exercício do seu poder regulamentar (competência normativa) $^{16}$.

Neste ponto, salutar a menção à Súmula TSE n 32 que assenta ser “inadmissível Recurso Especial Eleitoral por violação à legislação municipal ou estadual, ao Regimento Interno dos Tribunais Eleitorais ou às normas partidárias". No mesmo sentido, confira-se manifestação do TSE:

[...] 4. A ofensa a lei municipal, como arguido, não constitui hipótese de cabimento do recurso especial eleitoral, cuja fundamentação vincula-se à contrariedade de disposição expressa da Constituição da República ou de lei federal e/ou divergência na interpretação de lei entre dois ou mais tribunais eleitorais, consoante se extrai do enunciado da Súmula no 32/TSE.

(TSE, REspEl - Agravo Regimental no Recurso Especial Eleitoral no 060029187 - SANTO HIPÓLITO - MG. Acórdão de 12/11/2020. Relator(a) Min. Edson Fachin. Publicação: PSESS - Publicado em Sessão, Data 12/11/2020).

Por fim, em sede de juízo de admissibilidade, ao levantar esta hipótese de cabimento buscando o trânsito do Recurso Especial Eleitoral, a parte recorrente deve fazer constar, em suas razões, não somente menção expressa ao dispositivo de lei eleitoral que a decisão recorrida tenha contrariado, mas também demonstrar as razões desta ofensa legal frente aos fatos estabelecidos no acórdão regional recorrido.

\footnotetext{
${ }^{16}$ Código Eleitoral. "Art. 21. Os Tribunais e juízes inferiores devem dar imediato cumprimento às decisões, mandados, instruções e outros atos emanados do Tribunal Superior Eleitoral'. [...]

"Art. 23 - Compete, ainda, privativamente, ao Tribunal Superior: [...] IX - expedir as instruções que julgar convenientes à execução deste Código”.

Lei no 9504/95. "Art. 105. Até o dia 5 de março do ano da eleição, o Tribunal Superior Eleitoral, atendendo ao caráter regulamentar e sem restringir direitos ou estabelecer sanções distintas das previstas nesta Lei, poderá expedir todas as instruções necessárias para sua fiel execução, ouvidos, previamente, em audiência pública, os delegados ou representantes dos partidos políticos.".
} 


\subsubsection{Divergência na interpretação de lei entre dois ou mais tribunais eleitorais (dissídio jurisprudencial)}

Há, ainda, a possibilidade de se fundamentar o Recurso Especial Eleitoral na hipótese em que o acórdão recorrido tenha divergido da interpretação de lei conferida por outro tribunal regional eleitoral ou pelo TSE. A terceira hipótese de cabimento é baseada, portanto, no dissídio jurisprudencial, previsto no art. 276, I, "b", do Código Eleitoral e art. 121, \ 4º II, da $\mathrm{CF} / 88$.

Conforme orientação das normas que regem este fundamento de REspEl, a divergência deve ocorrer entre o acórdão regional recorrido e outra decisão colegiada proveniente de tribunais eleitorais.

Assim, estão excluídos dessa hipótese de cabimento: a) transcrições de trechos de parecer no MPE (AgR-REspe nº 27947, de 15/9/2009), b) resoluções derivadas de consultas administrativas ( Respe no 26171, de 9/11/2006), c) decisões monocráticas (AgR-AI no 6061, de 2/2/2006), d) acórdãos do STJ (REspe no 25094, de 16/6/2005), de TJ (AI no 2577, de 1/3/2001) e do STF (AgR-REspe no 17713, de 24/10/2000) ${ }^{17}$, e) Súmulas do TSE (REspe $n^{\circ}$ 31512, de 3/11/2008), f) julgados do mesmo tribunal ${ }^{18}$ (AgR-AI no 6208, de 19/12/2005).

Portanto, é sempre importante que o recorrente especial, representado por seu advogado, tenha conhecimento da jurisprudência mais recente do Tribunal Eleitoral que tomará como paradigma de sua irresignação, em relação ao que foi julgado no acórdão recorrido.

Assim, é primordial que a divergência alegada seja atual, considerando que a mutabilidade da composição das Cortes Eleitorais é relativamente alta, o que pode causar alteração no entendimento em relação a determinada matéria, de uma eleição para outra.

\footnotetext{
${ }^{17}$ Há críticas doutrinárias em relação à impossibilidade de interposição do REspEl com base em divergência de acórdão regional com julgado do STF. Aduz-se que o citado julgamento do AgR em Respe nº 17713 pelo TSE não teria aprofundado o debate acerca do tema, bem como que a Corte Suprema seria de fato e de direito um tribunal eleitoral, por deter competência para conhecer e julgar, em grau de recurso, matéria eleitoral.

${ }^{18}$ Súmula TSE no 29: "A divergência entre julgados do mesmo Tribunal não se presta a configurar dissídio jurisprudencial apto a fundamentar recurso especial eleitoral".
} 
De importância ímpar para o advogado eleitoralista, ao elaborar as razões do Recurso Especial Eleitoral, é o cumprimento do que dispõe o art. 1029, \ 1을 do CPC, bem como a Súmula TSE nº 28.

Assim:

Art. $1029[\ldots]$

$\int 1^{\circ}$ Quando o recurso fundar-se em dissídio jurisprudencial, o recorrente fará a prova da divergência com a certidão, cópia ou citação do repositório de jurisprudência, oficial ou credenciado, inclusive em mídia eletrônica, em que houver sido publicado o acórdão divergente, ou ainda com a reprodução de julgado disponível na rede mundial de computadores, com indicação da respectiva fonte, devendo-se, em qualquer caso, mencionar as circunstâncias que identifiquem ou assemelhem os casos confrontados.

Súmula TSE $\mathrm{n}^{\mathrm{Q}}$ 28: A divergência jurisprudencial que fundamenta o recurso especial interposto com base na alínea b do inciso I do art. 276 do Código Eleitoral somente estará demonstrada mediante a realização de cotejo analítico e a existência de similitude fática entre os acórdãos paradigma e o aresto recorrido.

Por cotejo analítico, entenda-se a argumentação comparativa, o confronto entre o acórdão recorrido e a decisão paradigma. Busca-se na instância superior o provimento do Recurso Especial para reformar o acórdão regional à luz do entendimento exarado pelo tribunal eleitoral que se usa como paradigma.

Dessa forma, a demonstração do dissídio jurisprudencial objetiva convencer o tribunal superior que o acórdão regional merece reforma por estar divergindo de outra decisão que, com similitude comprovada dos fatos e nos mesmos termos dos argumentos recursais, seria a mais acertada.

Sob o ponto de vista do Magistrado, necessária se faz a uniformização da jurisprudência eleitoral, tornando-a harmônica em todo o País. Para tanto, a análise, ainda em juízo de admissibilidade, deve partir de subsídios sólidos, claros, trazidos pelo recorrente.

Assim, não basta que o acórdão paradigma seja citado no bojo do recurso para que esta hipótese de cabimento permita o trânsito do REspEl pelo juízo de admissibilidade. É necessário que haja cotejo analítico de ambos os casos, comprovando-se a semelhança entre os fatos e a divergência no enquadramento jurídico dado a eles. 
Assim entende o Tribunal Superior Eleitoral:

[...] 6. O dissídio jurisprudencial, um dos alicerces da tese de que o recorrente é parte legítima, não ficou comprovado - não se perfaz com a mera transcrição de ementas e de trechos de acórdãos de julgados -, porquanto não realizado o cotejo analítico para verificação da similitude fática entre a decisão atacada e os paradigmas colacionados, conforme exige a Súmula no $28 /$ TSE.

(TSE, REspEl - Recurso Especial Eleitoral no 060016028 - PALHOÇA - SC. Acórdão de 18/12/2020. Relator(a) Min. Tarcisio Vieira De Carvalho Neto. Publicação: PSESS - Publicado em Sessão, Data 18/12/2020).

[...] 4. O agravante, ao realizar o cotejo entre os acórdãos confrontados, se limitou a copiar os trechos da ementa e dos votos proferidos, não cotejando os aspectos fáticos envolvidos, necessários para demonstrar a similitude entre o caso em apreço e os acórdãos colacionados. 5. A jurisprudência desta Corte Superior é firme no sentido de que "o requisito da divergência jurisprudencial somente se aperfeiçoa quando demonstrada a existência de similitude fática e realizado o cotejo analítico entre os julgados contrapostos, por força da Súmula no 28 do TSE”' (AgR-AI 759-09, rel. Min. Edson Fachin, DJE de 29.10.2018).

(TSE, REspEl - Agravo Regimental em Recurso Especial Eleitoral $\mathrm{n}^{\mathrm{o}} 060218978$ - PORTO ALEGRE - RS. Acórdão de 20/08/2020. Relator(a) Min. Sergio Silveira Banhos. Publicação: DJE - Diário da justiça eletrônica, Tomo 178, Data 04/09/2020, Página 0).

De modo a cumprir os contornos da Súmula TSE n² 28, a experiência prática demonstra que o uso de tabela comparativa nas razões do Recurso Especial é bastante didático, facilitando e simplificando a visualização pelo julgador dos argumentos do recorrente, no que se refere à exposição da similitude fática e do cotejo analítico da divergência na interpretação legal entre os tribunais eleitorais.

É importante ter em mente que, nas razões do REspEl sob o fundamento de dissídio jurisprudencial (art. 276, I, “b”, do Código Eleitoral e art. 121, \ $4^{\circ}, \mathrm{II}, \mathrm{da} \mathrm{CF} / 88$ ), ausente o foco argumentativo na comparação dos casos, e não se comprovando a similitude fática entre eles, a consequência fatal e corriqueira é a inadmissão do Recurso Especial Eleitoral ainda nos tribunais regionais. 
Considerando a flagrante exigência legal e jurisprudencial do cotejo analítico entre os casos recorrido e paradigma, é importante citar uma relativização da regra julgada pelo TSE, que, por maioria, entendeu pela sua desnecessidade, uma vez que estaria bastante nítida a similitude fática partindo da simples leitura das ementas divergentes mencionadas no bojo do recurso. Confira-se:

[...] 2. No agravo interno, o Parquet argui apenas que o recurso especial não deveria ter sido conhecido, pois não se indicou de forma expressa o comando normativo em tese violado, tampouco se realizou o cotejo analítico entre os arestos divergentes, nos termos do que dispõe o art. 276, I, $a$ e $b$, do Código Eleitoral. 3. Todavia, não se vislumbra deficiência no apelo que impeça a sua admissibilidade, ressaltando-se que ele foi interposto com base em "divergência na interpretação de lei entre dois ou mais tribunais eleitorais”. 4. É possível relativizar a formalidade acerca do pressuposto do dissídio jurisprudencial quando ele é notório. Precedentes do Superior Tribunal de Justiça sobre a matéria, destacando-se o AgInt-REspe 1548929/ SC, Rel. Min. Marco Aurélio Bellizze, 3ํㅜ Turma, DJE de 19/2/2020. 5. Na espécie, a simples leitura das ementas dos arestos colacionados nas razões recursais a título de dissídio pretoriano evidencia de modo inequívoco que a tese do candidato se relaciona à possibilidade de provar, por meio de testemunhas, a desincompatibilização de fato. (TSE, REspEl - Agravo Regimental em Recurso Especial Eleitoral $n^{\circ}$ 060046838 - MAGÉ - RJ. Acórdão de 27/11/2020. Relator(a) Min. Luis Felipe Salomão).

Apesar da exceção citada, ao invocar esta hipótese de cabimento para o Recurso Especial Eleitoral, e como forma de mitigar os riscos de inadmissão envolvidos, sugere-se sempre o cumprimento da exigência legal e a enfática defesa comparativa e argumentativa da similitude fática entre o acórdão recorrido e o paradigma.

\section{Considerações finais}

O Recurso Especial Eleitoral é recurso de natureza extraordinária que funciona como apelo ao TSE frente a acórdãos dos tribunais regionais. Diante do alto percentual de inadmissão dos recursos especiais eleitorais, este trabalho foi planejado para trazer um equilíbrio entre o pleno exercício do direito de recurso pela parte vencida e as normas que, em juízo de 
admissibilidade, filtram aqueles que não observam os requisitos legais e constitucionais, apenas protelando o desfecho processual em seu desfavor, em frontal colisão com a razoabilidade.

Por vezes chamadas pelos críticos de jurisprudência defensiva, o que lhe impõe forte carga conceitualmente negativa, as decisões reiteradas dos tribunais em juízo de admissibilidade são trilhadas para obstaculizar o exame do mérito de recursos que não carregam os necessários pressupostos legais e/ou são carecedores de hipótese legal para interposição.

Nesse diapasão, é importante registrar que a análise sensata do processo pela parte vencida, através de um estudo pormenorizado dos autos, especialmente das razões de decidir, associada a uma preparação atenta e prévia, resulta, na maioria dos casos, em sucesso do apelo especial futuro, de forma que o seu seguimento não seja fatalmente afetado pelas normas que fundamentam a análise do juízo de admissibilidade.

Ademais, a boa-fé processual também deve nortear as partes, inclusive para, na certeza da sucumbência justa e legal, evitar afogar os tribunais, já tão assoberbados com um sem número de recursos que, diariamente, lhes são submetidos a julgamento.

Assim, diante do panorama aqui traçado, e valendo-se dos contornos que individualizam o Recurso Especial Eleitoral, sua natureza, pressupostos e hipóteses de cabimento, conclui-se que é possível à parte vencida demonstrar habilidade, ainda na instância ordinária, preparando os autos para a interposição recursal justa e ultrapassar, com sucesso, o crivo do juízo de admissibilidade.

\section{Referências}

ALVIM, Frederico Franco. Manual de direito eleitoral. Belo Horizonte: Fórum, 2012.

ARAUJO, Eduardo Borges Espíndola; XIMENES, Júlia Maurmann. Contencioso eleitoral em tempos de judicialização da política: a disputa no Supremo e o Supremo na disputa. Rev. Investig. Const., Curitiba, v. 6, n. 2, p. 423448, Ago. 2019. Disponível em: <http://www.scielo.br/scielo.php?script=sci_arttext\&pid=S2359-56392019000200423\&lng=en\&nrm=iso $>$. Acesso em 08 Fev. 2021. Epub Jan 31, 2020. 
BARROS, Francisco Dirceu; PAES, Janiere Portela Leite. Recursos eleitorais. 2. ed. Leme (SP): JH Mizuno, 2016.

BRASIL. Constituição (1988). Constituição da República Federativa do Brasil. Brasília, DF: Senado Federal: Centro Gráfico, 1988.

BRASIL. Tribunal Superior Eleitoral. Código eleitoral anotado e legislação complementar. 13. ed. Brasília: Tribunal Superior Eleitoral, 2018.

Estruturalmente semelhantes, Respe e RO têm pecu-

liaridades quanto ao seu escopo. Disponível em: <https://www.tse.jus.br/ imprensa/noticias-tse/2019/Marco/estruturalmente-semelhantes-respe-e-ro-tem-peculiaridades-quanto-ao-seu-escopo >. Acesso em: 05 fev. 2021.

. Súmulas contribuem para agilizar os julgamentos da

Justiça Eleitoral. Disponível em: $<$ https://www.tse.jus.br/imprensa/noticias-tse/2017/Janeiro/sumulas-contribuem-para-agilizar-os-julgamentos-da-justica-eleitoral>. Acesso em: 02 fev. 2021.

CASTILHOS, Ângelo Soares. Breves notas sobre o recurso especial eleitoral e o novo Código de Processo Civil. Revista Jus Navigandi, Teresina, ano 20, n. 4400, 19 jul. 2015. Disponível em: <https://jus.com.br/artigos/40996>. Acesso em: 16 fev. 2021.

COSTA, Tito. Recursos em matéria eleitoral. 9 ed. rev. atual. e ampl. São Paulo: Editoria Revista dos Tribunais, 2010.

FREITAS, Theonio. O novo CPC e a jurisprudência defensiva. Revista Jus Navigandi, Teresina, ano 20, n. 4319, 29 abr. 2015. Disponível em: <https://jus.com.br/artigos/38552>. Acesso em: 22 mar. 2021.

GOMES, José Jairo. Recursos eleitorais. 5. ed. rev. atual. e ampl. São Paulo: Atlas, 2020.

GONÇALVES, Luís Carlos Santos. Direito eleitoral. 3. ed. São Paulo: Atlas, 2018.

MARINONI, Luis Guilherme; MITIDIERO, Daniel. Recurso extraordinário e recurso especial: do jus litigatoris ao jus constitutionis. 2. ed. rev. atual. e ampl. Revista dos Tribunais: São Paulo, 2020.

OLIVEIRA, João Paulo. Competência regulamentar do tribunal superior eleitoral e ativismo judicial. Revista Jus Navigandi. Disponível em: <https:/ / jus.com.br/artigos/77840/competencia-regulamentar-do-tribunal-superior-eleitoral-e-ativismo-judicial>. Acesso em 15 fev. 2021. 
TAVARES, Diogenes de Brito. É preciso defender-se da jurisprudência defensiva. Revista Consultor Jurídico. Disponível em: < https://www. conjur.com.br/2020-set-04/diogenes-tavares-defender-jurisprudencia-defensiva >. Acesso em: 04 fev. de 2021.

ZILIO, Rodrigo López. Direito eleitoral. 7. ed. Salvador: JusPodivm, 2020.

Viviane Medeiros Lima - Especialista em Direito Eleitoral (UFMA). Analista Judiciário do Tribunal Regional Eleitoral do Maranhão. vivianemlima5@gmail.com. ORCID: 00000002-0726-5584.

Volgane Oliveira Carvalho - Mestre em Direito (PUCRS). Analista Judiciário do Tribunal Regional Eleitoral do Maranhão. Secretário-Geral Adjunto da Academia Brasileira de Direito Eleitoral e Político (ABRADEP). Autor dos livros: "Manual das Inelegibilidades" e "Direitos Políticos no Brasil: o eleitor no Século XXI". volgane.carvalho@gmail.com. ORCID: 0000-0003-0501-4041. 